DOI https://doi.org/10.33766/2524-0323.86.182-190

УДК 342.92

P. В. Ігонін,

доктор юридичних наук, доцент, керівник

Департаменту з питань запобігання політичній корупції Національного агентства з питань запобігання корупції (м. Київ, Україна) e-mail: carlobambini17@gmail.com (iD https://orcid.org/0000-0003-3660-4036

М. В. Вікторчук, кандидат юридичних наук, головний спеціаліст Національного агентства з питань запобігання корупції (м. Київ, Україна) e-mail: m.v.kocherhan@nuwm.edu.ua (iD http://orcid.org/0000-0001-5197-5914

\title{
ПОНЯТТЯ ТА ОСОБЛИВОСТІ АДМІНСТРАТИВНИХ ПРОЦЕДУР
}

У статті розглянуто особливості адміністративних процедур як правового явища, визначено поняття «адміністративна процедура», проаналізовано ознаки адміністративних процедур. Проаналізовано наукові підходи щодо розмежування понять «адміністративна процедура», «адміністративний процес» та «адміністративне провадження». Зроблено висновок, що адміністративний процес є одним з видів правового процесу, і охоплює діяльність суб'єктів права щодо здійснення правового регулювання суспільних відносин і реалізації норм права.

Ключові слова: адміністративна процедура, адміністративний процес, адміністративне провадження, органи виконавчої влади, правове регулювання адміністративних процедур, управлінська діяльність.

Постановка проблеми. Головною ознакою розвитку держави $\epsilon$ спрямованість ії законодавства на забезпечення прав і законних інтересів осіб у відносинах із нею та іï органами. Конституція України проголошує головним обов'язком держави утвердження й забезпечення прав і свобод людини і громадянина, а також встановлює принцип, згідно з яким саме ці права і свободи та їх гарантії визначають зміст і спрямованість діяльності держави (стаття 3 Конституції України). У свою чергу органи державної влади та органи місцевого самоврядування, їх посадові особи зобов'язані діяти лише на підставі, у межах повноважень та у спосіб, що передбачені Конституцією та законами України (частина друга статті 19). Це, по-перше, забезпечує рівність осіб перед законом, адже до всіх однопорядкових справ застосовується однакова процедура, а по-друге, існування законодавчо встановленої процедури є вихідною точкою для здійснення контролю, зокрема судового, за законністю діяльності органів влади.

(C) Ігонін Р. В.,

Вікторчук М. В., 2019 
Проте відносин органів виконавчої влади i органів місцевого самоврядування, їх посадових осіб та інших суб'єктів, які законом уповноважені здійснювати владні управлінські функції, 3 громадянами регулюються переважно підзаконними нормативно-правовими актами. Тому необхідність дослідження порядку діяльності органів виконавчої влади й органів місцевого самоврядування, їх посадових осіб та інших суб'єктів, які законом уповноважені здійснювати владні управлінські функції, й особливо їх відносин із приватними особами, сьогодні не викликає сумнівів.

Аналіз останніх досліджень і публікацій. Питанням визначення сутності адміністративної процедури, ㄲï співвідношення 3 іншими поняттями у своїх працях приділяли увагу такі науковці, як: Т. Ф. Весельська, Н. В. Галіцина, О. С. Лагода, А. М. Луцик, К. В. Ростовська, Р. С. Тихий, Ю. М. Фролов та інші. Однак сьогодні не існує єдиної точки зору щодо вирішення цієї проблеми, зокрема не визначеним залишається питання співвідношення поняття «адміністративна процедура» 3 такими суміжними поняттями як «адміністративний процес» та «адміністративне провадження». Вирішення цього питання дозволить з'ясувати правову природу досліджуваного поняття та визначити основні напрямки його використання в управлінській діяльності та науці адміністративного права.

Формування цілей. Метою статті $є$ дослідження сутності адміністративної процедури, що передбачає визначення іiі ознак та співвідношення з іншими поняттями в адміністративному праві.

Виклад основного матеріалу. У теорії адміністративного права обгрунтовуються різні підходи до визначення сутності адміністративної процедури. Багато вчених наголошують, що поняття «адміністративна процедура» тісно пов'язане з поняттям «адміністративний процес». Деякі автори вважають ці поняття тотожними.

Перш ніж визначити поняття «адміністративна процедура», звернемо увагу на більш загальні категорії - «процедура», «юридична (правова) процедура». Термін «процедура» від латинського «procedo» означає «проходжу, або просуваюсь» $[1$, с. 234]. В узагальненому розумінні «процедура» - це певна сукупність дій або операцій, за допомогою яких реалізується той чи інший процес або етап, стадія, що виражає зміст відповідної технології [2, с. 166]. У сфері правових відносин процедура набуває статусу правової (юридичної), тобто вона є врегульованим нормою права порядком (послідовністю) здійснення юридично значущих дій у тій чи іншій сфері суспільного життя, які мають юридичне значення й наслідки [3, с. 671; 4, с. 45]. Так І. В. Панова під юридичною процедурою розуміє встановлений законодавством порядок здійснення юридичних дій, спрямованих на досягнення юридичного результату [5, с. 28].

Роль юридичної процедури в сучасній державі суттєво зростає, оскільки правовий режим в державі має визначатися технологією реалізації юридичних приписів. Р.С. Тихий вважає, що за допомогою правової процедури органи виконавчої влади визначають порядок розв'язання управлінської ситуації, у тому числі конкретної юридичної справи. 3 урахуванням цього підходу адміністративна процедура розглядається як 
нормативне впорядкування діяльності органів виконавчої влади, що регулює порядок прийняття владних управлінських рішень посадовими особами, у тому числі щодо розгляду й вирішення конкретних адміністративних справ. У свою чергу під адміністративним процесом слід розуміти юрисдикційну діяльність органів виконавчої і судової влади щодо розгляду адміністративних справ, справ про адміністративні правопорушення та застосування заходів адміністративного примусу. У цьому контексті адміністративна процедура розглядається як одна зі складових адміністративного процесу [6, с. 10].

Як зазначає О.С. Лагода,правова процедура має такі ознаки: а) встановлює порядок застосування правових норм для досягнення необхідного результату; б) положення, які визначають правові процедури, закріплюються в законах; в) синхронність, тобто з виникненням основної норми відразу приймається процедурна, що забезпечує нерозривність правотворчості та правореалізації та інші [7, с. 13; 8, с. 10].

Отже, під правовою процедурою слід розуміти законодавчо встановлені засоби реалізації норм права, які спрямовані на досягнення цілей правового регулювання тієї чи іншої сфери суспільних відносин та застосування яких має юридично-значущі наслідки.

Співвідносячи поняття адміністративної процедури й адміністративного процесу слід відзначити, що в сучасній адміністративноправовій науці існують різні концепції розуміння поняття адміністративного процесу. Так В. П. Тимощук виділяє такі концепції:

а) деліктну, яка включає відносини щодо розгляду справ про адміністративні правопорушення та застосування заходів адміністративного примусу;

б) юрисдикційну, яка охоплює відносини щодо розгляду справ про адміністративні правопорушення та адміністративне судочинство;

в) адміністративно-юстиційну, яка включає відносини щодо розгляду скарг в адміністративному порядку та адміністративне судочинство;

г) управлінську, що включає діяльність усіх органів публічної адміністрації;

д) позитивно-управлінську (охоплює діяльність органів публічної адміністрації, за винятком відносин щодо розгляду справ про адміністративні правопорушення);

е) широку (ідеться про всі відносини щодо застосування адміністративно-правових норм будь-якими суб'єктами, а також застосування в низці випадків матеріальних норм інших галузей права) [9, с. 34].

Такий широкий спектр розуміння адміністративного процесу пов'язаний iз тим, що в науці поняття адміністративного процесу розглядається у вузькому та широкому розуміннях. Адміністративний процес у вузькому розумінні - це діяльність уповноважених органів державної влади щодо розгляду справ про адміністративні правопорушення та застосування 
заходів адміністративного примусу. У широкому розумінні адміністративний процес, окрім зазначеної діяльності, включає управлінську діяльність щодо розгляду і розв'язання конкретних справ, які виникають у сфері державного управління, тобто передбачає не тільки юрисдикційну, а й регулятивну, нормотворчу та правозахисну діяльність публічної адміністрації [2, с. 165].

Зауважимо, що дискусійною є широка концепція розуміння поняття адміністративного процесу. Адже адміністративний процес грунтується на нормах адміністративного процесуального права, а його обов'язковим суб'єктом є виконавчі органи держави, їх посадові особи або інші уповноважені на реалізацію норм матеріального адміністративного права суб'єкти публічної адміністрації, органи судової влади [10, с. 12]. У свою чергу відповідно до широкої концепції застосування адміністративноправових норм в адміністративному процесі здійснюється будь-якими суб'єктами.

Вбачається, що недоцільно виділяти й деліктну концепцію, адже відносини щодо розгляду справ про адміністративні правопорушення включає юрисдикційна концепція, а відносини щодо застосування заходів адміністративного примусу - управлінська концепція.

Крім того, звернемо увагу, що більшість із вказаних концепцій поєднують юрисдикційний та позитивно-управлінський процес в одному понятті, що, на нашу думку, не відповідає сучасній адміністративно-правовій науці. 3 огляду на це, виникає необхідність у розмежуванні понять «адміністративний процес» та «адміністративна процедура».

Досліджуючи сутність адміністративного процесу та адміністративної процедури, Ю. І. Мельникова вказує, що поняття «процес» і «процедура» визначають порядок діяльності із застосування норм матеріального права. При цьому будь-яка процедура здійснення юридично значущих дій має визнаватись юридичним процесом перш за все на тій підставі, що вона $є$ юридичною формою опосередкування суспільних відносин із реалізації матеріальних прав та відносин [11, с. 14]. У свою чергу, О. В. Кузьменко зазначає, що, на відміну від процесу, процедура не є явищем, наділеним часовою динамікою: у процедурі відсутня головна детермінанта процесу тривалість у часовому вимірі, тобто процес наділяється такими ознаками, як динаміка, безперервний рух, що виражається в послідовних переходах від одного до іншого стану, а процедура визначається як дискретність такого pyxy [12, с. 167].

На думку Л. Л. Попова, адміністративні процедури - це процедури здійснення різних видів позитивної управлінської діяльності (процедури нормотворчої діяльності, процедури реалізації прав і обов' язків громадян та організацій у сфері управління, процедури контрольної діяльності), а також процедури, пов'язані 3 організацією роботи апарату органів виконавчої влади. Така діяльність характеризується як організаційно-процедурна, що здійснюється органами виконавчої влади в процесі реалізації своїх функцій [13, с. 222]. Р. С. Тихий адміністративні процедури пропонує розглядати як нормативну регламентацію діяльності органів виконавчої 
влади, що забезпечує порядок прийняття владних управлінських рішень посадовими особами, у тому числі розгляду і вирішення конкретних адміністративних справ [6, с. 74].

А В. Філатова визначає адміністративну процедуру як нормативноправове закріплення (правову модель) певних видів діяльності, що реалізуються в межах адміністративних правовідносин і відбиваються в певній, встановленій законом, правовій формі [14, с. 92]. На думку О. С. Лагоди, під адміністративною процедурою слід розуміти встановлений законом порядок розгляду та розв' язання індивідуальних адміністративний справ органом виконавчої влади і місцевого самоврядування, який закінчується прийняттям адміністративного акта або укладанням адміністративного договору [7, с. 18].

У науковій літературі визначають адміністративну процедуру як нормативно врегульовану послідовно здійснювану діяльність органів виконавчої влади із реалізації прав та обов'язків, що забезпечує порядок прийняття владних управлінських рішень посадовими особами (розгляд й вирішення адміністративних справ) [10, с. 13]. Тобто адміністративна процедура - врегульована адміністративно-процедурними нормами послідовність дій суб'єктів нормотворчої і правозастосовної діяльності, структурованих відповідними процедурними відносинами, щодо прийняття нормативно-правових актів управління та вирішення адміністративних справ.

У довідковій літературі поняття адміністративної процедури тлумачиться у вузькому та широкому значеннях. Згідно 3 першим адміністративна процедура - це порядок розгляду та вирішення уповноваженим органом державної влади (переважно органом виконавчої влади) конкретних індивідуальних справ, пов' язаних зі зверненнями громадян та організацій до відповідного органу з метою реалізації чи захисту своїх прав і законних інтересів. Адміністративна процедура регулюється законом або підзаконним нормативним актом (порядок розгляду скарг громадян, правила реєстрації юридичних осіб, правила видачі ліцензій, дозволу на носіння, зберігання, перевезення зброї тощо). У більш широкому розумінні адміністративна процедура є порядком здійснення органом виконавчої влади, посадовою особою встановлених для них повноважень (порядок розроблення, обговорення й прийняття правового акта, оформлення документа, що має юридичне значення, порядок прийому особи на державну службу, проходження атестації та оформлення відповідних документів, порядок розгляду матеріалів про заохочення службовців, про притягнення до дисциплінарної відповідальності; порядок оформлення контрольнонаглядової діяльності тощо) [15, с. 131].

Зважаючи на вказане, адміністративний процес і адміністративна процедура - це дві взаємопов'язані, однак цілком самостійні правові категорії. Адміністративний процес та адміністративні процедури об'єднують загальні властивості, а саме:1) здійснюються державними органами та їх посадовими i службовими особами;2) врегульовуються процесуальними нормами; 3) полягають в реалізації норм матеріального права в певній послідовності, 
порядку i за правилами, під час якої виникають, змінюються або припиняються конкретні суспільні відносини [15, с. 132-133].

Однак зауважимо, що на відміну від адміністративної процедури, результатом адміністративного процесу завжди є прийняття владного акта (постанови, вироку, рішення, протоколу та ін.).

Висновки. На підставі проведеного аналізу можна виділити такі особливості адміністративних процедур:

1) адміністративні процедури застосовуються в публічній сфері;

2) адміністративні процедури застосовуються при здійсненні правозастосовної діяльності;

3) адміністративні процедури охоплюють управлінську діяльність позитивної спрямованості, тобто діяльність, спрямовану на створення умов для ефективної реалізації прав і законних інтересів громадян та організацій;

4) адміністративні процедури спрямовані на упорядкування діяльності уповноважених органів виконавчої влади.

5) для адміністративних процедур характерний особливий суб'єктний склад (однією зі сторін в адміністративній процедурі завжди виступає державний орган або посадова особа, наділені державно-владними повноваженнями);

6) адміністративні процедури закріплюються адміністративнопроцесуальними нормами, які, своєю чергою, регулюють застосування матеріальних норм адміністративного та інших галузей права (фінансового, господарського, трудового та ін.) і при цьому регламентують діяльність уповноважених органів і посадових осіб.

Отже, адміністративний процес є видом юридичного процесу, діяльністю суб'єктів права щодо здійснення правового регулювання суспільних відносин та реалізації норм права, а процедура як частина адміністративного процесу $є$ врегульованою положеннями адміністративно-процесуального законодавства, не пов'язана з розглядом спорів або застосуванням примусових заходів правозастосовної діяльності щодо порядку підготовки і прийняття рішень органів виконавчої влади.

Перспективним напрямом подальших наукових розробок є дослідження, спрямовані на вдосконалення практичного застосування адміністративних процедур, розробку та прийняття окремого нормативно-правового акту про адміністративні процедури в Україні.

\section{Використані джерела:}

1. Гончаренко В. Г., Андрушко П. П., Базова Т. П. Юридичні терміни: тлумачний словник. Київ: Либідь, 2003. 320 с.

2. Галіцина Н. В. Адміністративна процедура як інститут адміністративного процесу. Форум права. 2010. № 4. C. 163-177. URL: http://www.nbuv.gov.ua/ejournals/FP/2010-4/10gnviap.pdf.

3. Матузов Н. И., Малько А. В. Теория государства и права: ученик. Москва: Юристъ, 2004. 541 с. 
4. Николина К. Належна юридична процедура: теоретичні аспекти визначення. Вісник Київського національного університету імені Тараса Шевченка. Юридичні науки. 2012. № 94. С. 44-46.

5. Панова И. В., Конин Н.М.Юридический процесс. Саратов: Светопись, 1998. $76 \mathrm{c}$.

6. Тихий Р. С. Проблемы правового регулирования административных процедур в Российской Федерации: дис. ... канд. юрид. наук: 12.00.14. Тюмень, 2005. 222 c.

7. Лагода О. С. Адміністративна процедура: теорія і практика застосування: дис. ... канд. юрид. наук : 12.00.07. Ірпінь, 2007. 187 с.

8. Гусаров С., Білоус В. Визначення понять адміністративної процедури та адміністративного процесу в адміністративному праві України. Вісник Академіі управління МВС. 2008. № 3. С. 6-18.

9. Тимощук В.П. Адміністративні акти: процедура прийняття та припинення : монографія. Київ: Конус-Ю, 2010. 296 с.

10. Бандурка О. М., Тищенко М. М. Адміністративний процес. Київ: Літера ЛТД, 2002. 288 с.

11. Мельников Ю. И. К вопросу о соотношении «юридического процесса» и «юридической процедуры». Актуальные проблемы юридического процесса в общенародном государстве. Москва. 1979. Вып. 1. С. 13-15.

12. Кузьменко О. В. Теоретичні засади адміністративного процесу: монографія. Київ: Атіка, 2005. 352 с.

13. Попов Л. Л. Административное право Российской Федерации. Москва: Юрайт, 2010. 444 с.

14. Филатова А. В. Регламенты и процедуры в сфере реализации государственного контроля (надзора). Саратов, 2009. 208 с.

15. Демський Е. Ф. Адміністративне процесуальне право України. Київ: Юрінком Інтер, 2008. 495 с.

\section{References}

1. Honcharenko V. H., Andrushko P. P., Bazova T. P. Yurydychni terminy: tlumachnyi slovnyk [Glossary of legal terms]. Kyiv: Lybid, 2003: 320 (In Ukrainian).

2. Halitsyna N. V. Administratyvna protsedura yak instytut administratyvnoho protsesu [The Administrative Procedure as Institute of Administrative Process]. Forum prava. 2010; No 4: 163-177. Available from: http://www.nbuv.gov.ua/ejournals/FP/2010-4/10gnviap.pdf (In Ukrainian).

3. Matuzov N. Y., Malko A. B. Teoryia hosudarstva y prava [The theory of state and law]. Moskva: Yuryst, 2004: 541 (In Ukrainian).

4. Nykolyna K. Nalezhna yurydychna protsedura: teoretychni aspekty vyznachennia [The Theoretical aspects of definition of due process of law]. Visnyk Kyivskoho natsionalnoho universytetu imeni Tarasa Shevchenka. Yurydychni nauky. 2012; No 94: 44-46 (In Ukrainian).

5. Panova I. V., Konin N. M. Yuridicheskiy protsess [Legal process]. Saratov: Svetopis. 1998: 76 (In Russia).

6. Tihiy R. S. Problemyi pravovogo regulirovaniya administrativnyih protsedur v Rossiyskoy Federatsii [Problems of legal regulation of administrative procedures in the Russian Federation]. D.Sc (Ph.D.) dissertation. Tyumen. 2005: 222 (In Russia). 
7. Lahoda O. S. Administratyvna protsedura: teoriia i praktyka zastosuvannia [Theory and practice of application administrative procedure]. D.Sc (Ph.D.) dissertation. Irpin. 2007: 187 (In Ukrainian).

8. Husarov S., Bilous V. Vyznachennia poniat administratyvnoi protsedury ta administratyvnoho protsesu $\mathrm{v}$ administratyvnomu pravi Ukrainy [The definition of concepts «administrative procedure» and «administrative process» in the administrative law of Ukraine]. Visnyk Akademii upravlinnia MVS. 2008; No 3: 6-18 (In Ukrainian).

9. Tymoshchuk V. P. Administratyvni akty: protsedura pryiniattia ta prypynennia [Administrative acts: procedure of acceptance and termination]. Kyiv: Konus-Yu. 2010: 296 (In Ukrainian).

10. Bandurka O. M., Tyshchenko M. M. Administratyvnyi protses [Administrative process]. Kyiv: Litera LTD. 2002: 288 (In Ukrainian).

11. Melnikov Yu. I. K voprosu o sootnoshenii «yuridicheskogo protsessa» i «yuridicheskoy protseduryi». Aktualnyie problemyi yuridicheskogo protsessa v obschenarodnom gosudarstve [The relation between concepts «administrative procedure» and «administrative process»]. Moskva. 1979; No 1. 13-15 (In Russia).

12. Kuzmenko O. V. Teoretychni zasady administratyvnoho protsesu [Theoretical basis of administrative process]. Kyiv: Atika. 2005: 352 (In Ukrainian).

13. Popov L. L. Administrativnoe pravo Rossiyskoy Federatsii. Moskva: Yurayt. 2010: 444 (In Russia).

14. Filatova A. V. Reglamentyi i protseduryi v sfere realizatsii gosudarstvennogo kontrolya (nadzora) [Regulations and procedures in the field of implementation of state control (supervision)]. Saratov. 2009: 208 (In Russia).

15. Demskyi E. F. Administratyvne protsesualne pravo Ukrainy [Administrative Procedural Law of Ukraine]. Kyiv: Yurinkom Inter. 2008: 495 (In Ukrainian).

Стаття надійшла до редколегї 26.05.2019

Игонин Р. В., доктор юридических наук, доцент, начальник Департамента по вопросам предупреждения политической коррупции, Национального агентства по вопросам предупреждения коррупції (г. Киев, Украина) Викторчук М. В., кандидат юридических наук, главный специалист Национального агентства по вопросам предупреждения коррупции (г. Киев, Украина)

\section{ПОНЯТИЕ И ОСОБЕННОСТИ АДМИНИСТРАТИВНЫХ ПРОЦЕДУР}

В статье рассмотрены особенности административных процедур как правового явления, определено понятие «административная процедура», проанализированы признаки административных процедур. Проанализированы научные подходы по разграничению понятий «административная процедура», «административный процесс» и «административное производство». Сделан вывод, 
что административный процесс является одним из видов правового процесса, и охватывает деятельность субъектов права по осуществлению правового регулирования общественных отношений и реализации норм права.

Ключевые слова: административная процедура, административный процесс, административное производство, органы исполнительной власти, правовое регулирование административных процедур, управленческая деятельность.

Ihonin R., doctor of Law, associate professor, head of department prevention of political corruption, National agency for the prevention of corruption

(Kiev, Ukraine)

Viktorchuk M., candidate of jurisprudence, head specialist of the national agency for Nutrition and public health

(Kiev, Ukraine)

\section{THE CONTENT AND FEATURING OF ADMINISTRATIVE PROCEDURES}

The article describes the features of the administrative procedure as a legal phenomenon, gives the interpretation of the definition of "administrative procedure", and analyzes signs of the administrative procedure. The purpose of the article is to research definition of administrative procedure, to consider the main characteristics and featuring of administrative procedure.

The methodological basis of the paper is a set of general scientific and special methods of research. In particular, by using logical and semantic, comparative and legal methods the author has defined a list of feature of the administrative procedure.

The scientific approaches to the key categories of the legal regulation of the administrative procedure are investigated.

In article analyzed scientific approaches concerning a difference between concepts «administrative procedure», «administrative process» and «administrative realization». It has been emphasized that administrative process and administrative procedure are two interrelated, but independent legal categories. The administrative process and the administrative procedure are performed by specially authorized bodies of executive power and their officials and officials, are regulated by procedural norms, consist in the implementation of the rules of substantive law.

Also in the article that conclusions are that the administrative process is a type of legal process and covers the activities of subjects of the right in relation to implementation of legal regulation of social relations and the implementation of the rules of law.

Fragmentary references to specific administrative procedures were reflected in separate legal acts, however, a full-fledged act, the purpose of which is to regulate the institute of administrative procedures, is still in development. Therefore, adoption of a normative act that would streamline all questions regarding administrative procedures is a promising direction for further scientific developments.

Key words: administrative procedure, administrative process, administrative realization, bodies of executive power, legal regulation of administrative procedures, management activity. 